\title{
Modern challenges in the education of young surgeons: the two sides of the coin
}

Education is a life-long process for every physician. Education quality determines the effectiveness of the whole healthcare system and safety for patients. That is the reason why the essential questions of medical education go over the generation to generation: what difficulties we face and what we can do better.

The residency is one of the most responsible and complicated steps in the surgical education. It is a time to polish theoretical knowledge acquired during medical school, to learn decision making, working in medical team and, of course, to work out practical skills. In case of any surgical specialization, it is a core part which can never be replaced or reduced.

Surgical training is a long-term process of finding balance between the hours that the resident should dedicate to learning, needed number of procedures performed by a resident, and the way skills are being learnt, either in the operation room or on simulators.

Modern surgery develops very quickly. New technologies appear in everyday life much faster that training program can adapt for it. Nevertheless, the quality of education should not be impacted by this fact. Challenges in modern surgical education must be discussed worldwide involving all sides: educators and residents.

In these series we present the most common problems of surgical practical education by mentor's and resident's point of view.

The coworking of all the authors was very productive and together we established the most important theses about each of the problems:

(I) Hours restriction policies—as well as the availability of tutors and a support network—are necessary to break this (vicious) cycle. Flexibility on applying the rules may be one strategy to avoid unwanted interruptions in patient care and residents' learning process (1). Therefore, the restriction of working hours should be a weekly average, with some heavier days and others lighter, shifts followed by rest and planned days off (2).

(II) Establish the minimal number of procedures for surgical resident we need to take into account many factors: residency duration, available equipment, individual characteristics of the resident. In some countries assessment scales for practical skills should be introduced $(3,4)$.

(III) Simulation is a key component of surgical education that should be formally integrated in every surgical residency curriculum. In addition, further efforts are needed to develop standardized simulation programs with validated simulators (5). Through simulation, residents can shorten the learning curve time of the great majority of surgical procedures (6).

We hope that all the topics covered in this special series will have a great response and may be, the wide discussion in professional circles will lead to changes in educational programs.

\section{Acknowledgments}

Funding: None.

\section{Footnote}

Provenance and Peer Review: This article was commissioned by the editorial office, AME Surgical fournal for the series "Modern Challenges in the Education of Young Surgeons: the Two Sides of the Coin". The article did not undergo external peer review.

Conflicts of Interest: Both authors have completed the ICMJE uniform disclosure form (available at https://asj.amegroups.com/ 
article/view/10.21037/asj-21-60/coif). The series "Modern Challenges in the Education of Young Surgeons: the Two Sides of the Coin" was commissioned by the editorial office without any funding or sponsorship. FAMH served as an unpaid Guest Editor of the series and serves as an unpaid editorial board member of AME Surgical fournal from February 2021 to January 2023. VR served as an unpaid Guest Editor of the series. The authors have no other conflicts of interest to declare.

Ethical Statement: The authors are accountable for all aspects of the work in ensuring that questions related to the accuracy or integrity of any part of the work are appropriately investigated and resolved.

Open Access Statement: This is an Open Access article distributed in accordance with the Creative Commons AttributionNonCommercial-NoDerivs 4.0 International License (CC BY-NC-ND 4.0), which permits the non-commercial replication and distribution of the article with the strict proviso that no changes or edits are made and the original work is properly cited (including links to both the formal publication through the relevant DOI and the license). See: https://creativecommons.org/ licenses/by-nc-nd/4.0/.

\section{References}

1. Nadaleto BF, Herbella FAM. Modern challenges in the education of young surgeons: the two sides of the coin-hours restriction: the resident's point of view. AME Surg J 2021. doi: 10.21037/asj-21-24.

2. Adão D. Hours restriction: mentors' point of view. AME Surg J 2021. doi: 10.21037/asj-21-25.

3. Lemeschewskij A, Raznitsyna V. Modern challenges in the education of young surgeons: the two sides of the coin—minimal number of procedures: mentor's point of view. AME Surg J 2021;1:3.

4. Raznitsyna V, Lemeschewskij A. Minimal number of procedures: resident's point of view. AME Surg J 2021. doi: 10.21037/asj21-30.

5. Schlottmann F. Simulation in surgical education: mentors' point of view. AME Surg J 2021. doi: 10.21037/asj-21-40.

6. Laxague F. Simulation in surgical education: resident's point of view. AME Surg J 2021. doi: 10.21037/asj-21-41.

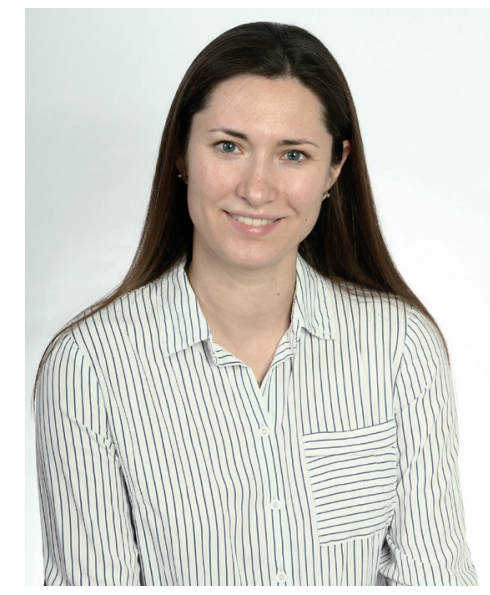

Volha Raznitsyna

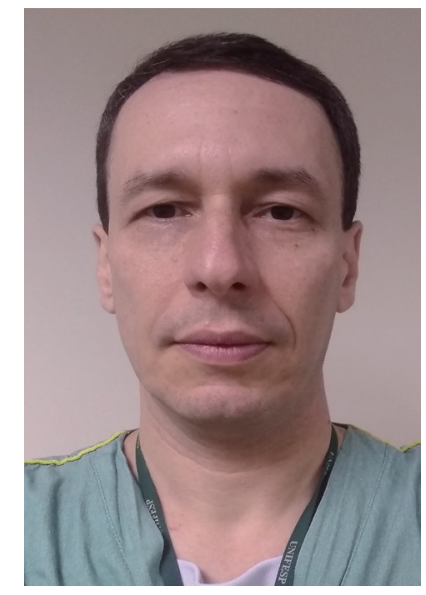

Fernando Augusto Mardiros Herbella 
Volha Raznitsyna^, MD Mogilev City Hospital, Mogilev, Belarus. (Email: olga.razni@mail.ru) Fernando Augusto Mardiros Herbella, MD, Associated Professor Department of Surgery, Federal University of São Paulo, São Paulo, Brasil. (Email: fherbella@gmail.com) Received: 05 July 2021; Accepted: 26 July 2021; Published: 30 September 2021. doi: $10.21037 / \mathrm{asj}-21-60$

View this article at: https://dx.doi.org/10.21037/asj-21-60

doi: 10.21037/asj-21-60

Cite this article as: Raznitsyna V, Herbella FAM. Modern challenges in the education of young surgeons: the two sides of the coin. AME Surg J 2021;1:12.

$\wedge$ ORCID: 0000-0003-0766-8487. 